\title{
Cakile maritima Scop. Extracts Inhibit CaCo2 and HeLa Human Carcinoma Cell Growth: GC-MS Analysis of an Anti-Proliferative Extract
}

\author{
Elsayed Omer ${ }^{1}$, Abdelsamed Elshamy ${ }^{2}$, Rihab Taher ${ }^{2}$, Walaa El-Kashak², Joseph Shalom ${ }^{3,4}$, \\ Alan White ${ }^{4}$, Ian Cock $^{3,4^{*}}$
}

\section{Elsayed Omer ${ }^{1}$, Abdelsamed Elshamy², Rihab Taher ${ }^{2}$, Walaa El- Kashak' ${ }^{2}$, Joseph Shalom ${ }^{3,4}$, Alan White ${ }^{4}$, Ian Cock $^{3,4^{*}}$}

'Department of Medicinal and Aromatic Plants Research, National Research Centre, Giza, EGYPT.

${ }^{2}$ Department of Chemistry and Natural Compounds, National Research Centre, Dokki, Giza, EGYPT.

${ }^{3}$ Environmental Futures Research Institute, Nathan Campus, Griffith University, 170 Kessels Rd, Nathan, Queensland 4111, AUSTRALIA. ${ }^{4} S$ chool of Natural Sciences, Nathan Campus, Griffith University, 170 Kessels Rd, Nathan, Queensland 4111, AUSTRALIA.

Correspondence

Dr. Ian E. Cock

School of Natural Sciences, Nathan Campus, Griffith University, 170 Kessels Rd, Nathan, Queensland 4111، AUSTRALIA.

Phone no : +61 737357637

E-mail: I.Cock@griffith.edu.au

History

- Submission Date: 11-09-2018.

- Review completed: 15-11-2018;

- Accepted Date: 23-11-2018.

DOI : 10.5530/pj.2019.11.40

Article Available online

http://www.phcogi.com/v11/i2

\section{Copyright}

(c) 2019 Phcog.Net. This is an openaccess article distributed under the terms of the Creative Commons Attribution 4.0 International license.

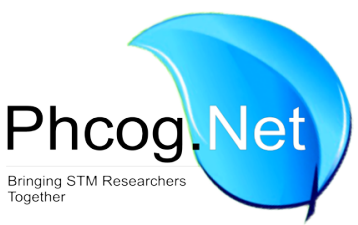

\begin{abstract}
Introduction: Exposure to high levels of antioxidants has been linked to the treatment and prevention of some cancers. Although Cakile maritima has a high antioxidant capacity, it is yet to be tested for the ability to inhibit the proliferation of cancer cells. Methods: Solvent extracts prepared from C. maritima plant material were analysed for antioxidant capacity by the DPPH free radical scavenging assay. Anti-proliferative activities against $\mathrm{CaCo} 2$ and HeLa cancer cells were determined by an MTS based cell proliferation assay. Toxicity was determined by the Artemia franciscana bioassay. The most potent anti-proliferative extract (hexane) was further investigated using non-targeted GC-MS headspace analysis. Results: Good DPPH radical scavenging activity was calculated for all $C$. maritima extracts. The methanolic and ethyl acetate extracts had particularly strong antioxidant activity $\left(\mathrm{IC}_{5}\right.$ of 4.7 and $3.4 \mu \mathrm{g} / \mathrm{mL}$ respectively). Interestingly, the hexane extract which had the lowest DPPH radical scavenging activity $\left(\mathrm{IC}_{50} 13.6 \mu \mathrm{g} / \mathrm{mL}\right)$, was the most potent inhibitor or $\mathrm{CaCo} 2$ and HeLa carcinoma cell growth, with $I C_{50}$ 's of 12 and $126 \mu \mathrm{g} / \mathrm{mL}$ respectively. The ethyl acetate extract was also a potent inhibitor of proliferation $\left(\mathrm{IC}_{50}\right.$ values of 185 and $468 \mu \mathrm{g} / \mathrm{mL}$ against CaCo2 and HeLa, respectively). The methanolic extract $\left(\mathrm{IC}_{5}\right.$ values of 2261 and $2046 \mu \mathrm{g} / \mathrm{mL}$ against $\mathrm{CaCo} 2$ and HeLa respectively) displayed only moderate anti-proliferative activity, demonstrating that antioxidant activity did not correspond with anti-proliferative activity. All of the extracts were determined to be nontoxic in the Artemia franciscana bioassay, with $\mathrm{LC}_{50}$ values substantially $>1000 \mu \mathrm{g} / \mathrm{mL}$. Non-biased GC-MS headspace analysis of the $C$. maritima hexane extract highlighted several interesting compounds that may contribute to the therapeutic bioactivities of the extract. Conclusion: The lack of toxicity and the anti-proliferative activity of the hexane and ethyl acetate $\mathrm{C}$. maritima extracts against HeLa and $\mathrm{CaCo} 2$ cancer cell lines indicates their potential in the treatment and prevention of some cancers.
\end{abstract}

Key words: Brassicaceae, European searocket, Antioxidant, Oxidative stress, Caco2, HeLa, Anticancer activity.

\section{INTRODUCTION}

Regulation of cellular redox state is important to maintain the function and well-being of individual cells and of the whole organism. When cellular redox regulatory mechanisms are unable to cope effectively with the production of Reactive oxygen species (ROS), the cell is placed under oxidative stress and the ROS may induce significant damage to cellular proteins and lipids, thereby negatively influencing the cells survival. Excessive oxidative stress and the inability to overcome it has been implicated in numerous diseases including atherosclerosis diabetes, cirrhosis, ${ }^{1}$ autoimmune disease and chronic inflammation, ${ }^{2}$ neurodegeneration ${ }^{1}$ and cancer. ${ }^{3}$ The relationship between cellular redox state and cancer progression has been particularly well studied and the induction of cellular oxidative stress has been linked with several types of cancer., ${ }^{4,5}$ As well as damaging cellular proteins and lipids, ROS may also

induce the formation of DNA adducts which may promote carcinogenic activity. An understanding of cellular redox regulation is important for the identification of new targets for the development of drugs to prevent and treat cancers.

Cells regulate their redox state by balancing the levels of oxidants and antioxidants by both enzymatic and non-enzymatic mechanisms. The antioxidant defensive enzymes include catalase, thioredoxin, thioredoxin reductase, superoxide dismutase, glutathione reductase and glutathione peroxidase. ${ }^{6}$ The non-enzymatic antioxidant defences include glutathione, as well as vitamins A, C and E. Interestingly, high dietary intakes of non-enzymatic antioxidants decrease the incidence of chronic diseases including some cancers. ${ }^{7}$ High antioxidant herbal medicines 
and culinary plants contain multiple phenolic compounds that are strong antioxidants. ${ }^{8}$ Many of these compounds can scavenge ROS, protect cell constituents against oxidative damage and thereby prevent carcinogenesis and retard the disease's progression. Thus, high antioxidant plant extracts may be useful for both preventing and treating some cancers.

Cakile maritima Scop. (Family Brassicaceae; commonly known as European searocket) is a herb which is native to Europe and the northern parts of Africa. It can survive in harsh conditions, thrives in sandy, coastal regions, often displaces native local taxa and has become widely naturalised internationally. C. maritima grows to $40 \mathrm{~cm}$ in height and has a multi-branched stem. All parts of the plant have a high antioxidant capacity and are particularly rich in ascorbic acid..$^{9}$ The entire plant is consumed, particularly when other food sources are scarce. ${ }^{10}$ It is most frequently used as a flavouring agent, although young raw leaves may also be eaten fresh in salads. The powdered C. maritima roots can also be used to make bread. Furthermore, its high antioxidant capacity provides C. maritima with medicinal potential as high dietary intake of non-enzymatic antioxidants has been linked with decreased incidence of some chronic diseases, including some cancers, chronic inflammation, atherosclerosis and Alzheimer's disease. ${ }^{1,11}$ Indeed, individuals with elevated dietary intakes of non-enzymatic antioxidants such as vitamins $\mathrm{A}, \mathrm{C}$ and $\mathrm{E}$ are less likely to suffer from some diseases including cancer and chronic inflammation. ${ }^{1}$ Furthermore, several studies have demonstrated bacterial growth inhibitory and anti-inflammatory activities for several culinary plants with high antioxidant capacities and have linked the bioactivities to their free radical scavenging activities. ${ }^{12-16} \mathrm{~A}$ recent study from our group also reported good antibacterial activity for C. maritima whole plant extracts. ${ }^{17}$ Despite this, we were unable to find reports examining the anticancer activity of C. maritima.

\section{MATERIALS AND METHODS}

\section{Plant source and extraction}

The aerial parts of Cakile maritima Scop. were collected and identified by Dr. Ahmed M. Abd El-Gawad, from Kafr-Saad, Damietta Governorate, Egypt in April 2015. A voucher specimen (Code No: CAM-311-015) was deposited at the herbarium of the Botany Department, Faculty of Science, Mansoura University, Egypt. The C. maritima aerial parts were air-dried in the shade and $1 \mathrm{~kg}$ of dried plant material were subsequently pulverized to a coarse powder. The powder was macerated in $70 \%$ methanol ( $5 \mathrm{~L}$ ) at room temperature for five days, filtered and evaporated under vacuum, yielding a dark resinous extract $(58 \mathrm{~g})$. The dried extract was dissolved in $1 \mathrm{~L}$ of distilled water and successively fractionated using $n$-hexane, ethyl acetate and methanol respectively (each in $0.5 \mathrm{~L}$ of solvent, three times). Each fraction was separately dried under vacuum to yield 10.5, 15.0 and 32.5 gm of dried extracted material respectively

\section{Qualitative phytochemical studies}

The extracts were analysed for the presence of saponins, phenolic compounds, flavonoids, phytosterols, triterpenoids, cardiac glycosides, anthraquinones, tannins and alkaloids by previously described assays. ${ }^{18-20}$

\section{Antioxidant capacity}

The antioxidant capacity of each sample was assessed using a modified DPPH free radical scavenging method. ${ }^{17}$ Briefly, DPPH solution was prepared as a $400 \mu \mathrm{M}$ solution by dissolving DPPH (Sigma, Australia) in AR grade methanol (Ajax, Australia). The C. maritima extracts were diluted in methanol across the concentration range $10-80 \mu \mathrm{g} / \mathrm{mL}$. Aliquots $(20 \mu \mathrm{L})$ of each extract were mixed with $80 \mu \mathrm{L}$ of $100 \mathrm{mM}$ Tris- $\mathrm{HCl}$ buffer ( $\mathrm{pH}$ 7.4). Ascorbic acid was prepared fresh and examined across the range $0-25 \mu \mathrm{g}$ per well as a reference. A volume of $100 \mu \mathrm{L}$ of DPPH solution was added to each well to give a volume of $250 \mu \mathrm{L}$. Blanks for each extract or ascorbic acid concentration, were also included on each plate. The assay mixtures were incubated in the dark for $20 \mathrm{~min}$ at $23^{\circ} \mathrm{C}$ and the absorbance were recorded at $515 \mathrm{~nm}$ using a Molecular Devices, Spectra Max M3 plate reader. All tests were performed in triplicate and triplicate controls were included on each plate. The \% DPPH decolourisation was calculated using the following formula:

$$
\% \text { decolorisation }=\left[1-\left(\mathrm{A}_{\text {test }} / \mathrm{A}_{\text {control }}\right)\right] \times 100
$$

$\mathrm{IC}_{50}$ values were determined as the test concentration capable of scavenging $50 \%$ of the DPPH radicals via linear regression.

\section{Screen for anticancer bioactivity Cancer cell lines}

The $\mathrm{CaCo}_{2}$ and $\mathrm{HeLa}$ carcinoma cell lines used in this study were obtained from American Type Culture Collection (Rockville, USA). The cells were cultured in Roswell Park Memorial Institute (RPMI) 1640 medium (Life Technologies), supplemented with $20 \mathrm{mM}$ HEPES, $10 \mathrm{mM}$ sodium bicarbonate, $50 \mu \mathrm{g} / \mathrm{mL}$ streptomycin, $50 \mathrm{IU} / \mathrm{mL}$ penicillin, $2 \mathrm{mM}$ glutamine and $10 \%$ foetal calf serum (Life Technologies). The cells were maintained as monolayers in $75 \mathrm{~mL}$ flasks at $37^{\circ} \mathrm{C}, 5 \% \mathrm{CO}_{2}$ in a humidified atmosphere until approximately $80 \%$ confluent.

\section{Evaluation of cancer cell anti-proliferative activity}

Anti-proliferation of the extracts was assessed as previously described. ${ }^{21}$ Briefly, $70 \mu \mathrm{L}$ of cell culture containing approximately 5000 cells was added to the wells of a 96 well plate and $30 \mu \mathrm{L}$ of the test extracts or cell media (for the negative control) was added to individual wells. The plates were then incubated at $37^{\circ} \mathrm{C}, 5 \% \mathrm{CO}_{2}$ for $12 \mathrm{~h}$ in a humidified atmosphere. A volume of $20 \mu \mathrm{L}$ of Cell Titre 96 Aqueous One solution (Promega) was added to each well and the plates were incubated for a further $3 \mathrm{~h}$. The absorbance was measured at 490nm using a Molecular Devices, Spectra Max M3 plate reader. All tests were performed in at least triplicate, with 3 internal repeats $(n=9)$ and triplicate controls were included on each plate. The anti-proliferative activity of each test was calculated as a percentage of the negative control using the following formula:

$$
\text { Proliferation }(\% \text { untreated control })=\left(\mathrm{A}_{\mathrm{ct}} / \mathrm{A}_{\mathrm{cc}}\right) \times 100
$$

$A_{c t}$ is the corrected absorbance for the test extract (calculated by subtracting the absorbance of the test extract in media without cells from the extract cell test combination) and $\mathrm{A}_{c c}$ is the corrected untreated control (calculated by subtracting the absorbance of the untreated control in media without cells from the untreated cell media combination).

\section{Toxicity screening}

Potassium dichromate $\left(\mathrm{K}_{2} \mathrm{Cr}_{2} \mathrm{O}_{7}\right)$ (AR grade, Chem-Supply, Australia) was prepared in deionised water $(4 \mathrm{mg} / \mathrm{mL})$ and serially diluted in artificial seawater for use as a reference toxin. Toxicity of the C. maritima extracts, the reference toxin and the conventional antibiotics was assessed using a modified Artemia franciscana nauplii lethality assay. ${ }^{22,23}$ The $\mathrm{LC}_{50}$ with 95\% confidence limits for each treatment was calculated using probit analysis.

\section{Non-targeted GC-MS head space analysis}

Chromatographic separations were performed using a Shimadzu GC-2010 plus (USA) linked to a Shimadzu MS TQ8040 (USA) mass selective detector system as previously described. ${ }^{24}$ The system was equipped with a Shimadzu auto-sampler AOC-5000 (USA) fitted with a Supelco (USA) divinyl benzene/carbowax/polydimethylsiloxane (DVB/ CAR/PDMS) solid phase micro-extraction fibre (SPME) handling system. Chromatographic separation was accomplished using a 5\% phenyl, 95\% dimethylpolysiloxane $(30 \mathrm{~m} \times 0.25 \mathrm{~mm}$ id $\times 0.25 \mu \mathrm{m})$ capillary column 
(Restek USA). Helium was employed as a carrier gas at a flow rate of 0.79 $\mathrm{mL} / \mathrm{min}$ and an injector temperature of $230^{\circ} \mathrm{C}$. Sampling utilised a SPME cycle for a period of 10 min exposure to allow for absorption. The SPME was then desorbed in the injection port for $1 \mathrm{~min}$ at $250^{\circ} \mathrm{C}$. The initial column temperature was held at $30^{\circ} \mathrm{C}$ for $2 \mathrm{~min}$, increased to $140^{\circ} \mathrm{C}$ for $5 \mathrm{~min}$, then increased to $270^{\circ} \mathrm{C}$ over a period of $3 \mathrm{mins}$ and held at that temperature for the duration of the analysis. The GC-MS interface was maintained at $200^{\circ} \mathrm{C}$. No signal was acquired for the first minute following sample injection and the system was run in split-less mode. The mass spectrometer was operated in the electron ionisation mode at $70 \mathrm{eV}$ and the mass signals were recorded in total ion count (TIC) mode. Data acquisition began $1 \mathrm{~min}$ after injection and continued for $45 \mathrm{mins}$ utilising a mass range of $45-450 \mathrm{~m} / \mathrm{z}$.

\section{Statistical analysis}

Data are expressed as the mean \pm SEM of at least three independent experiments, each with internal triplicates $(n=9)$. One-way ANOVA was used to calculate statistical significance between control and treated groups, with a $P$ value $<0.01$ considered to be statistically significant.

\section{RESULTS}

\section{Liquid extraction yields, qualitative phytochemical screening and antioxidant capacity}

Extraction of $1 \mathrm{~kg}$ of C. maritima whole plant with 5L of $70 \%$ methanol yielded $58 \mathrm{~g}$ (i.e. $5.8 \%$ yield) of dried total extract (TE) (Table 1). Sequential extraction with hexane, ethyl acetate and methanol yielded $10.5 \mathrm{~g}$ (approximately $1.1 \%$ yield), $15.0 \mathrm{~g}$ (approximately $1.5 \%$ yield) and $32.5 \mathrm{~g}$ (approximately $3.3 \%$ yield) of total extracted material respectively. The dried extracts were resuspended in deionised water (containing 1\% DMSO) to give the extract concentrations shown in Table 1.

All extracts contained a wide range of phytochemical classes (Table 1). Phenolics and flavonoids were present in moderate-high levels in the ethyl acetate and methanolic extracts. Triterpenoids were present in all extracts, albeit in low relative abundance. Saponins were present in methanolic and ethyl acetate extracts in low relative abundance (but not in the hexane extract), whilst phytosterols were present in the methanolic and hexane extracts (but not in the ethyl acetate extract). Alkaloids were only present in the methanolic extract, albeit in low abundance. All extracts were completely devoid of cardiac glycosides, tannins and anthraquinones. Antioxidant capacity (expressed as the concentration capable of scavenging $50 \%$ of the DPPH radical) for the C. maritima extracts (Table 2) ranged from a DPPH radical scavenging $\mathrm{IC}_{50}$ of 3.4 $\mu \mathrm{g} / \mathrm{mL}$ (ethyl acetate C. maritime extract) to a high of $13.6 \mu \mathrm{g} / \mathrm{mL}$ (C. maritima hexane extract).

\section{Anti-proliferative activity}

Aliquots of all C. maritima extracts were tested for the ability to block cell proliferation of $\mathrm{CaCo}_{2}$ and $\mathrm{HeLa}$ cell lines. All C. maritima extracts tested displayed significant $(p<0.01)$ anti-proliferative effects against $\mathrm{CaCo} 2$ cells (Figure 1). The hexane extract was particularly potent and completely inhibited $\mathrm{CaCo} 2$ proliferation. The methanolic and ethyl acetate extracts were also potent inhibitors of $\mathrm{CaCo} 2$ proliferation, inhibiting cellular proliferation by approximately $95 \%$ compared to the untreated control $\mathrm{CaCo} 2$ cell proliferation. The $C$. maritima extracts were similarly effective at inhibiting HeLa cancer cell proliferation, with all C. maritima extracts displaying potent inhibitory activity (Figure 2). In contrast to $\mathrm{CaCo} 2$ proliferation, the mid polarity ethyl acetate extracts was the most effective inhibitor of HeLa proliferation ( $99 \%$ inhibition of proliferation). The methanolic and hexane extracts were also effective inhibitors of HeLa proliferation, decreasing growth by approximately $85 \%$ and $95 \%$ of the untreated control HeLa cell proliferation respectively.

The anti-proliferative efficacy of the extracts against CaCo2 and HeLa cells was further quantified by determining the dose required to inhibit to $50 \%\left(\mathrm{IC}_{50}\right)$ of the control cell proliferation (Table 2). The calculated $\mathrm{IC}_{50}$ values indicate that the order of efficacy for the extracts was hexane extract $>$ ethyl acetate extract $>$ methanol extract against both cell lines. The hexane $\left(\mathrm{IC}_{50} 12\right.$ and $126 \mu \mathrm{g} / \mathrm{mL}$ against $\mathrm{CaCo} 2$ and $\mathrm{HeLa}$ cells

Table 1: The mass of dried extracted material, the concentration after resuspension in deionised water, qualitative phytochemical screenings and antioxidant capacities of the C. maritima extracts.

\begin{tabular}{|c|c|c|c|c|c|c|c|c|c|c|c|c|c|c|c|c|}
\hline 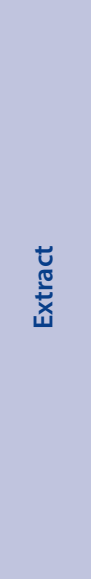 & 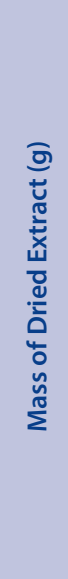 & 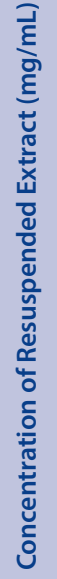 & 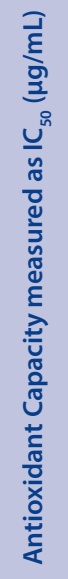 & $\begin{array}{l}\frac{\tilde{U}}{0} \\
\frac{0}{0} \\
\frac{\tilde{\sigma}}{2} \\
\frac{\pi}{0} \\
\stackrel{0}{0}\end{array}$ & 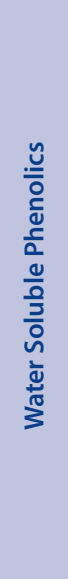 & 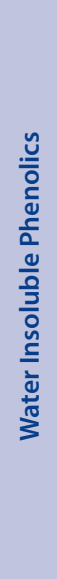 & 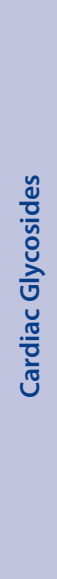 & 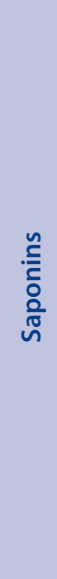 & 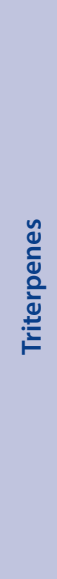 & 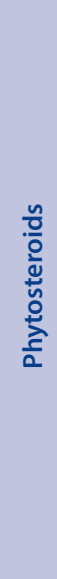 & 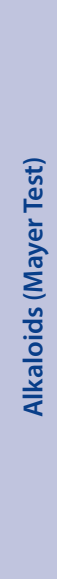 & 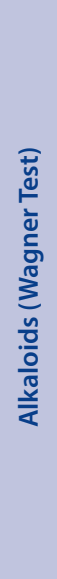 & $\begin{array}{l}\frac{n}{0} \\
\frac{0}{0} \\
\frac{0}{0} \\
\frac{\pi}{4}\end{array}$ & 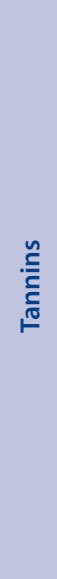 & 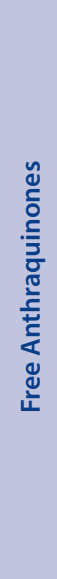 & 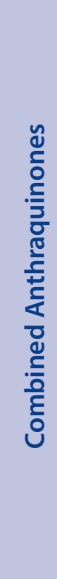 \\
\hline $\mathrm{TE}$ & 58 & 58 & 6.8 & NT & NT & NT & NT & NT & NT & NT & NT & NT & NT & NT & NT & NT \\
\hline CMM & 32.5 & 40 & 4.7 & +++ & +++ & ++ & - & + & + & + & + & + & +++ & - & - & - \\
\hline CME & 15.0 & 10 & 3.4 & +++ & ++ & ++ & - & + & + & - & - & - & ++ & - & - & - \\
\hline $\mathrm{CMH}$ & 10.5 & 6 & 13.6 & ++ & + & + & - & - & + & + & - & - & - & - & - & - \\
\hline
\end{tabular}

+++ indicates a large response; ++ indicates a moderate response; + indicates a minor response; - indicates no response in the assay; $\mathrm{NT}=\mathrm{not}$ tested. CMM = methanolic C. maritima extract; $\mathrm{CME}=$ ethyl acetate C. maritima extract; $\mathrm{CMH}=$ hexane C. maritima extract. Antioxidant capacity was determined by DPPH reduction and is expressed as the test concentration capable of scavenging $50 \%$ of the DPPH radical. 


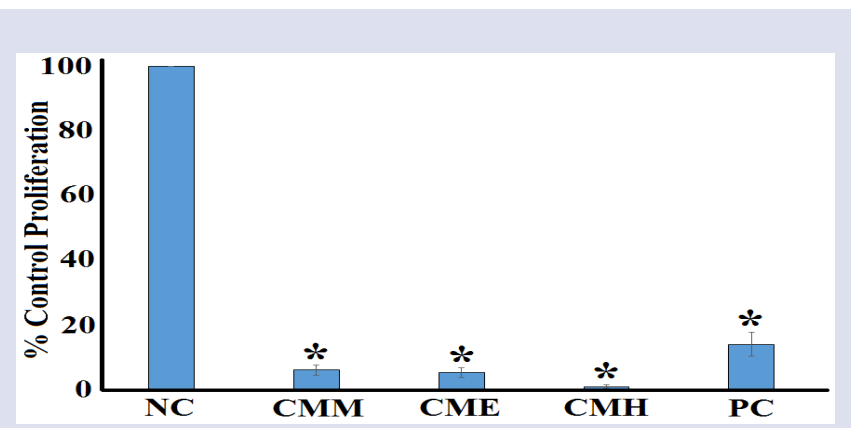

Figure 1: Anti-proliferative activity of the C. maritima extracts and untreated controls against $\mathrm{CaCO} 2$ cancer cells measured as percentages of the untreated control cells. NC = untreated cell growth (negative control); $\mathrm{CMM}=$ C. maritima methanolic extract; $\mathrm{CME}=$ C. maritima ethyl acetate extract; $\mathrm{CMH}=\mathrm{C}$. maritima hexane extract; $\mathrm{PC}=$ positive control (50 mg/mL cisplatin). Results are expressed as mean percentages \pm SEM of three independent tests, each with internal triplicate determinations $(n=9) .{ }^{*}$ indicates results that are significantly different to the untreated control $(p<0.01)$.

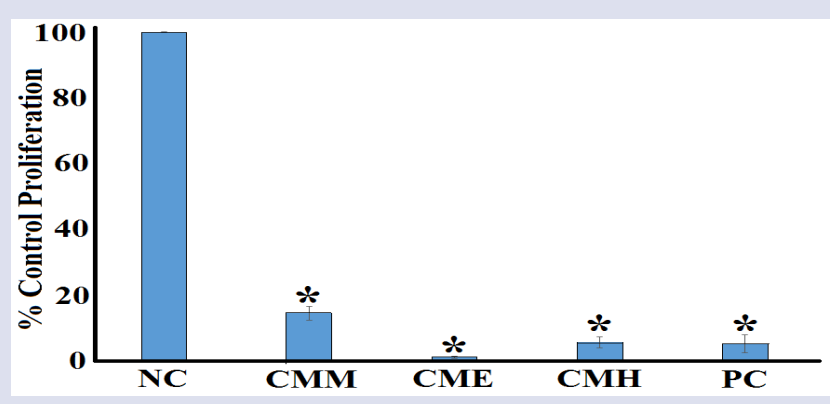

Figure 2: Anti-proliferative activity of the C. maritima extracts and untreated controls against HeLa cancer cells measured as percentages of the untreated control cells. NC = untreated cell growth (negative control); $\mathrm{CMM}=\mathrm{C}$. maritima methanolic extract; $\mathrm{CME}=\mathrm{C}$. maritima ethyl acetate extract; $\mathrm{CMH}=\mathrm{C}$. maritima hexane extract; $\mathrm{PC}=$ positive control $(50 \mathrm{mg} / \mathrm{mL}$ cisplatin). Results are expressed as mean percentages \pm SEM of three independent tests, each with internal triplicate determinations $(n=9) .{ }^{*}$ indicates results that are significantly different to the untreated control $(p<0.01)$.

respectively) and ethyl acetate extracts ( $\mathrm{IC}_{50} 185$ and $468 \mu \mathrm{g} / \mathrm{mL}$ against $\mathrm{CaCo} 2$ and HeLa cells respectively) were both potent inhibitors of the proliferation of both cell lines. In contrast, the methanolic extract displayed relatively low activity $\left(\mathrm{IC}_{50} 2261\right.$ and $2046 \mu \mathrm{g} / \mathrm{mL}$ against $\mathrm{CaCo} 2$ and HeLa cells respectively).

\section{Quantification of toxicity}

All extracts were initially screened undiluted in the assay (Figure 3). For comparison, the reference toxin potassium dichromate $(1000 \mu \mathrm{g} / \mathrm{mL})$ was also tested in the bioassay. The potassium dichromate reference toxin was rapid in its onset of mortality, inducing significant nauplii death within the first $4 \mathrm{~h}$ of exposure and $100 \%$ mortality within $5 \mathrm{~h}$ (results not shown). In contrast, the methanolic and hexane C. maritima extracts did not induce mortality rates significantly different from those of the untreated seawater control. However, the ethyl acetate extract induced
Table 2: The IC $\mathrm{C}_{50}$ values $(\mu \mathrm{g} / \mathrm{mL})$ of $\mathrm{CaCo} 2$ and HeLa human cancer cell lines and the $\mathrm{LC}_{50}$ values $(\mu \mathrm{g} / \mathrm{mL})$ for Artemia franciscana nauplii exposed to C. maritima extracts and control solutions.

\begin{tabular}{cccc}
\hline & $\begin{array}{c}\text { Antiproliferative Activity } \mathrm{IC}_{50} \\
(\mu \mathrm{g} / \mathrm{mL})\end{array}$ & Artemia nauplii $\mathrm{LC}_{50}(\mu \mathrm{g} / \mathrm{mL})$ \\
& $\mathrm{CaCo2}$ & HeLa & \\
\hline $\mathrm{CMM}$ & 2261 & 2046 & - \\
$\mathrm{CME}$ & 185 & 468 & 1361 \\
$\mathrm{CMH}$ & 12 & 126 & - \\
$\mathrm{PC}$ & 69 & 85 & 154 \\
\hline
\end{tabular}

Numbers indicate the mean $\mathrm{IC}_{50}$ or $\mathrm{LC}_{50}$ values of at least triplicate determinations. indicates no significant brine shrimp mortality was evident. $\mathrm{CMM}=$ C. maritima methanolic extract; $\mathrm{CME}=$ C. maritima ethyl acetate extract; $\mathrm{CMH}=$ C. maritima hexane extract; $\mathrm{PC}=$ positive control (cisplatin for anti-proliferative assays; potassium dichromate for toxicity assays).

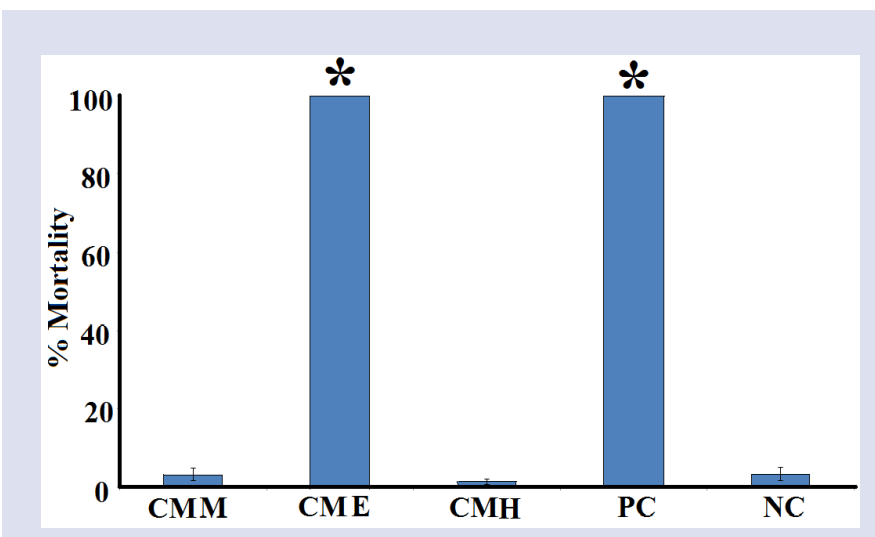

Figure 3: The lethality of the C. maritima extracts $(2000 \mu \mathrm{g} / \mathrm{mL})$ and the potassium dichromate control $(1000 \mu \mathrm{g} / \mathrm{mL})$ towards Artemia franciscana nauplii following $24 \mathrm{~h}$ exposure. $\mathrm{CMM}=\mathrm{C}$. maritima methanolic extract; $\mathrm{CME}=\mathrm{C}$. maritima ethyl acetate extract; $\mathrm{CMH}=\mathrm{C}$. maritima hexane extract; $\mathrm{NC}=$ negative (seawater) control; $\mathrm{PC}=$ positive control (1000 $\mu \mathrm{g} / \mathrm{mL}$ potassium dichromate). Results are expressed as mean percentages \pm SEM of three independent tests, each with internal triplicate determinations $(n=9) .{ }^{*}$ indicates results that are significantly different to the untreated control $(p<0.01)$.

$>50 \%$ mortality at $24 \mathrm{~h}$. Therefore, methanolic and hexane C. maritima extracts were deemed non-toxic, whilst the ethyl acetate extract was deemed toxic (based on the screening study mortality) and its level of toxicity was further evaluated.

To further quantify the effect of toxin concentration on the induction of mortality, the C. maritima ethyl acetate extract was serially diluted in artificial seawater to test across a range of concentrations in the Artemia nauplii bioassay. Table 2 shows the $\mathrm{LC}_{50}$ values of the $C$. maritima extracts towards $A$. franciscana. No $\mathrm{LC}_{50}$ values are reported for the methanolic and hexane extracts as $<50 \%$ mortality was seen for all concentrations tested. In contrast, a $24 \mathrm{~h} \mathrm{LC}_{50}$ value of $1361 \mu \mathrm{g} / \mathrm{mL}$ was determined for the ethyl acetate extract. As $\mathrm{LC}_{50}>1000 \mu \mathrm{g} / \mathrm{ml}$ towards Artemia nauplii for crude extracts have been defined nontoxic, ${ }^{25}$ the ethyl acetate was also deemed to be non-toxic.

\section{Non-targeted GC-MS headspace analysis}

As the C. maritima hexane extract had the most potent anti-proliferative activity against both the $\mathrm{CaCo} 2$ and $\mathrm{HeLa}$ cell lines (as determined by 
$\mathrm{IC}_{50}$; Table 2), it was deemed the most promising extract for further phytochemical evaluation by GC-MS metabolomics profiling. The resultant gas chromatogram is presented in Figure 4. Major peaks were evident in the C. maritima hexane extract at approximately $13.2,15.1,15.6,15.8$, $15.9,16.4,19.1,19.3,20.9,21.7,23.6$ and $24.2 \mathrm{~min}$. Several smaller peaks were also evident throughout all stages of the chromatograms. In total, 137 unique mass signals were noted for the C. maritima hexane extract (Table 3). Putative empirical formulas and identifications were achieved for 97 of these compounds (approximately $71 \%$ ) by comparison with the database. The major components by area were: Peak 1: 2-hydroxy-1, 8-cineole (12.7 $\mathrm{min} ; 1.2 \%$ of the total area under all chromatographic peaks; Figure $5 \mathrm{a}$ ). Peak 2: decane (13.2 min; $5.1 \%$ of the total area under all chromatographic peaks). Peak 3: limonene (14.1 min; $2.0 \%$ of the total area under all chromatographic peaks; Figure $5 b)$. Peak 4: citronellal (14.6 min; $0.4 \%$ of the total area under all chromatographic peaks; Figure 5c). Peak 5: 3, 3-dimethylhexane (15.1 min; $3.0 \%$ of the total area under all chromatographic peaks). Peak 6: m-tolualdehyde (15.6 min; $2.5 \%$ of the total area under all chromatographic peaks). Peak 7: isodecyl methacrylate (15.8 $\mathrm{min} ; 2.2 \%$ of the total area under all chromatographic peaks). Peak 8: 2,5-dimethyl-2-undecane (15.9 min; $2.6 \%$ of the total area under all chromatographic peaks). Peak 9: 2,5-dimethyl2-undecane (15.9 min; $2.6 \%$ of the total area under all chromatographic peaks). Peak 10: nonaldehyde (16.4 min; $5.0 \%$ of the total area under all chromatographic peaks). Peak 11: methyl salicylate (19.1 min; $3.2 \%$ of the total area under all chromatographic peaks). Peak 12: dodecane (19.4 min; $3.3 \%$ of the total area under all chromatographic peaks). Peak 13: 1,3-bis(1,1-dimethylethyl)-benzene (20.9 $\mathrm{min} ; 10.7 \%$ of the total area under all chromatographic peaks). Peak 14: 4,6-dimethyldodecane (21.7 min; $1.9 \%$ of the total area under all chromatographic peaks). Peak 15: 2,2,4-trimethyl-1,3-pentanediol diisobutyrate (23.6 $\mathrm{min} ; 6.0 \%$ of the total area under all chromatographic peaks); peak 16: propanoic acid, 2-methyl-3-hydroxy-2,2,4-trimethypentyl ester (24.2 min; $8.3 \%$ of the total area under all chromatographic peaks).

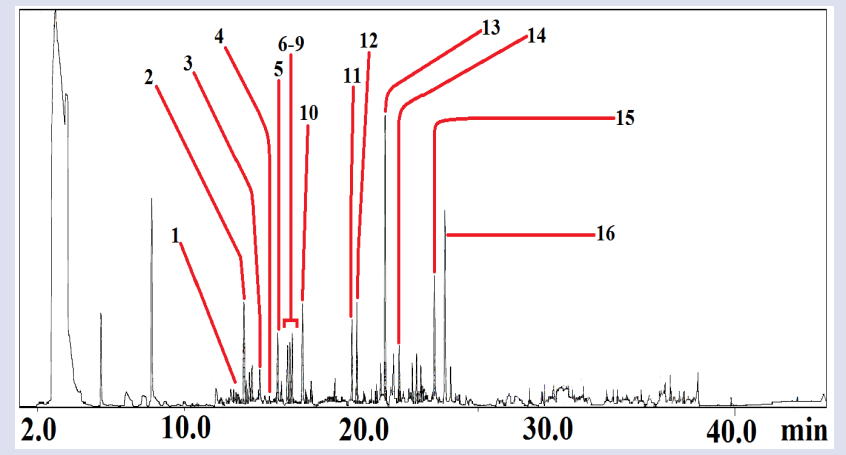

Figure 4: GC headspace total ion chromatogram of $0.5 \mu \mathrm{L}$ injection of C. maritima hexane extract. The extract was dried and resuspended in methanol for analysis. The major components (by \% prevalence) and some notable compounds are indicated on the chromatogram: (1) 2-hydroxy-1,8-cineole; (2) decane; (3) limonene; (4) citronellal; (5) 3,3-dimethylhexane; (6) m-tolualdehyde; (7) isodecyl methacrylate; (8) nonaldehyde; (9) 2,5-dimethyl-2-undecane; (10) nonaldehyde; (11) methyl salicylate; (12) dodecane; (13) 1,3-bis(1,1-dimethylethyl)-benzene; (14) 4,6-dimethyldodecane; (15) 2,2,4-trimethyl-1,3-pentanediol diisobutyrate; (16) propanoic acid, 2-methyl-3-hydroxy-2,2,4-trimethypentyl ester.
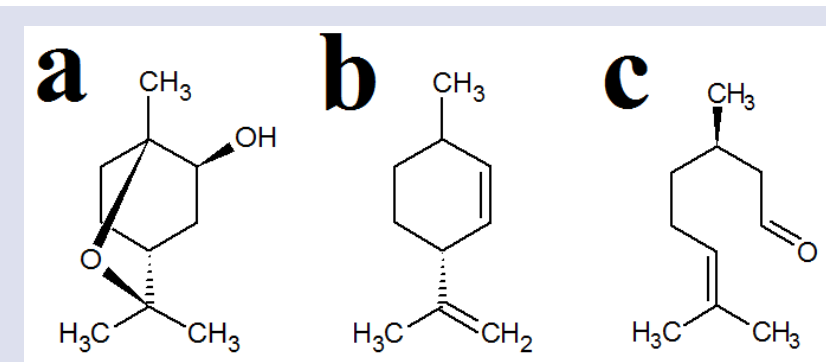

Figure 5: Chemical structures of monoterpenoid compounds detected in the C. maritima hexane extract by GC-MS headspace analysis: (a) 2-hydroxy-1,8-cineole; (b) limonene; (c) citronellal.

\section{DISCUSSION}

ROS, including superoxide radical $\left(\mathrm{O}_{2} \bullet^{-}\right)$, hydrogen peroxide $\left(\mathrm{H}_{2} \mathrm{O}_{2}\right)$ and hydroxyl radical $(\mathrm{OH} \bullet)$, place cells under oxidative stress and may induce damage to cellular proteins and lipids, reducing cellular survival. Cells respond to oxidative stress via both enzymatic and non-enzymatic mechanisms to minimise the effects of ROS. High intake of non-enzymatic antioxidants can scavenge ROS and has been linked with decreased incidence of some cancers. ${ }^{7}$ However, understanding the effects of high levels of antioxidants on cancer establishment and progression has proven to be complex, with the ability of plant extracts to exert antioxidant activity dependent on multiple factors. Antioxidant phytochemicals may function as either antioxidants or pro-oxidants, depending upon their relative concentration. ${ }^{26}$ For example, the anthraquinone aloe emodin exerts antioxidant activity at low concentrations, yet acts as a pro-oxidant at higher concentrations. In contrast, another anthraquinone (aloin) has antioxidants effect at high concentrations and pro-oxidant effects at low concentrations. Similar concentration dependent antioxidant/pro-oxidant effects have been reported for other antioxidant phytochemicals including flavonoids ${ }^{27}$ and tannins. ${ }^{28}$ Thus, individual phytochemicals may act as either antioxidants or pro-oxidants, dependent on their individual levels and on their relative abundances. Although an extract may have high antioxidant contents, the individual components may act either as antioxidants or as oxidants. Therefore, high antioxidant plant extracts may be effective in the treatment of cancer, as well as in its prevention at different concentrations.

The anti-proliferative efficacy of $C$. maritima extracts were examined against HeLa (cervical) and $\mathrm{CaCo} 2$ (colorectal) cancer cell lines. The C. maritima hexane extract (DPPH scavenging $\mathrm{IC}_{50}=13.6 \mu \mathrm{g} / \mathrm{mL}$ ) had the most potent anti-proliferative activities against the $\mathrm{CaCo} 2$ and $\mathrm{HeLa}$ cell lines, with $\mathrm{IC}_{50}$ values of 12 and $126 \mu \mathrm{g} / \mathrm{mL}$ respectively. This compares favourably with the $\mathrm{IC}_{50}$ values of the cisplatin control (69 and $85 \mu \mathrm{g} / \mathrm{mL}$ against $\mathrm{CaCo} 2$ and $\mathrm{HeLa}$ cells respectively). This is particularly impressive as the $C$. maritima hexane contains a crude mixture of phyto-compounds (only some of which would contribute to the antiproliferative activity), whereas cisplatin is a pure compound. Purification of the anti-proliferative extract component(s) may ultimately result in a therapy with far greater efficacy than cisplatin against these cell lines. The ethyl acetate extract was also a potent inhibitor of $\mathrm{CaCo} 2$ and $\mathrm{HeLa}$ proliferation ( $\mathrm{IC}_{50}$ values of 185 and $468 \mu \mathrm{g} / \mathrm{mL}$ respectively) and therefore also has potential for the development of cancer chemotherapies. The methanolic extract displayed only moderate anti-proliferative potency $\left(\mathrm{IC}_{50}\right.$ values in the range $2000-2300 \mu \mathrm{g} / \mathrm{mL}$ ) against both cell lines. Interestingly, the methanolic extract had substantially greater DPPH scavenging activity $\left(\mathrm{IC}_{50} 4.7 \mu \mathrm{g} / \mathrm{mL}\right)$ than the hexane extract, indicating that the anti-proliferative activity may not correlate directly with antioxidant activity. Similar trends have also been reported for apple skin 
Table 3: Qualitative headspace GC-MS analysis of the C. maritima hexane extract, elucidation of empirical formulas and putative identification (where possible) of the compounds.

\begin{tabular}{|c|c|c|c|c|}
\hline Retention Time (min) & Molecular Mass & Empirical Formula & Area $\%$ & Putative Identification \\
\hline 10.39 & 151 & $\mathrm{C}_{8} \mathrm{H}_{9} \mathrm{NO}_{2}$ & 0.09 & Methoxy-phenyl-oxime \\
\hline 11.72 & 112 & $\mathrm{C}_{7} \mathrm{H}_{12} \mathrm{O}$ & 1.36 & (E)-2-Heptenal \\
\hline 12.33 & 128 & $\mathrm{C}_{9} \mathrm{H}_{20}$ & 0.27 & 2,2,3,3-Tetramethylpentane \\
\hline 12.53 & 128 & $\mathrm{C}_{8} \mathrm{H}_{16} \mathrm{O}$ & 1.19 & 1-Octen-3-ol \\
\hline 12.74 & 170 & $\mathrm{C}_{10} \mathrm{H}_{18} \mathrm{O}_{2}$ & 1.21 & 2-Hydroxy-1,8-cineole \\
\hline 13.24 & 142 & $\mathrm{C}_{10} \mathrm{H}_{22}$ & 5.09 & Decane \\
\hline 13.54 & 142 & $\mathrm{C}_{10} \mathrm{H}_{22}$ & 1.40 & 3,3,5-Trimethylheptane \\
\hline 13.67 & 142 & $\mathrm{C}_{10} \mathrm{H}_{22}$ & 1.73 & 2,5,5-Trimethylheptane \\
\hline 13.87 & 120 & $\mathrm{C}_{9} \mathrm{H}_{12}$ & 0.15 & Ethyl-toluene \\
\hline 13.96 & 286 & $\mathrm{C}_{16} \mathrm{H}_{30} \mathrm{O}_{4}$ & 0.45 & Oxalic acid \\
\hline 14.10 & 136 & $\mathrm{C}_{10} \mathrm{H}_{16}$ & 1.99 & D-Limonene \\
\hline 14.63 & 154 & $\mathrm{C}_{10} \mathrm{H}_{18} \mathrm{O}$ & 0.41 & Citronellal \\
\hline 14.99 & 168 & $\mathrm{C}_{12} \mathrm{H}_{24}$ & 0.27 & (3Z)-9-Methyl-3-undecane \\
\hline 15.09 & 114 & $\mathrm{C}_{8} \mathrm{H}_{18}$ & 2.96 & 3,3-Dimethylhexane \\
\hline 15.26 & 184 & $\mathrm{C}_{13} \mathrm{H}_{28}$ & 0.79 & Isobutylnonane \\
\hline 15.35 & 124 & $\mathrm{C}_{9} \mathrm{H}_{16}$ & 0.17 & 2-Nonyne \\
\hline 15.46 & 130 & $\mathrm{C}_{8} \mathrm{H}_{18} \mathrm{O}$ & 0.28 & 1-Octanol \\
\hline 15.62 & 120 & $\mathrm{C}_{8} \mathrm{H}_{8} \mathrm{O}$ & 2.53 & m-Tolualdehyde \\
\hline 15.75 & 226 & $\mathrm{C}_{14} \mathrm{H}_{26} \mathrm{O}_{2}$ & 2.17 & Isodecyl methacrylate \\
\hline 15.88 & 182 & $\mathrm{C}_{13} \mathrm{H}_{26}$ & 2.64 & 2,5-Dimethyl-2-undecane \\
\hline 16.25 & 184 & $\mathrm{C}_{13} \mathrm{H}_{28}$ & 0.17 & 5-Isobutylnonane \\
\hline 16.44 & 142 & $\mathrm{C}_{9} \mathrm{H}_{18} \mathrm{O}$ & 4.99 & n-Nonaldehyde \\
\hline 16.64 & 156 & $\mathrm{C}_{11} \mathrm{H}_{24}$ & 0.43 & 6-Ethyl-2-methloctane \\
\hline 16.79 & 134 & $\mathrm{C}_{10} \mathrm{H}_{14}$ & 0.66 & 1,3-Dimethylbenzene \\
\hline 16.92 & 134 & $\mathrm{C}_{10} \mathrm{H}_{14}$ & 1.01 & o-Cymene \\
\hline 17.06 & 126 & $\mathrm{C}_{9} \mathrm{H}_{18}$ & 0.03 & 3,5,5-Trimethylhexene \\
\hline 17.25 & 172 & $\mathrm{C}_{11} \mathrm{H}_{24} \mathrm{O}$ & 0.05 & 2-Isopropyl-5-methyl-1-heptanol \\
\hline 18.09 & 286 & $\mathrm{C}_{16} \mathrm{H}_{30} \mathrm{O}_{4}$ & 0.31 & Oxalic acid, 2-ethylhexyl isohexyl ester \\
\hline 18.33 & 184 & $\mathrm{C}_{13} \mathrm{H}_{28}$ & 0.18 & 5-Sec-butylnonane \\
\hline 18.44 & 144 & $\mathrm{C}_{8} \mathrm{H}_{16} \mathrm{O}_{2}$ & 0.10 & Octanoic acid \\
\hline 18.52 & 170 & $\mathrm{C}_{12} \mathrm{H}_{26}$ & 0.03 & 3,8-Dimethyldecane \\
\hline 18.67 & 314 & $\mathrm{C}_{18} \mathrm{H}_{34} \mathrm{O}_{4}$ & 0.20 & Oxalic acid, 6-ethyloct-3-yl hexyl ester \\
\hline 19.13 & 152 & $\mathrm{C}_{8} \mathrm{H}_{8} \mathrm{O}_{3}$ & 3.20 & Methyl salicylate \\
\hline 19.31 & 150 & $\mathrm{C}_{10} \mathrm{H}_{14} \mathrm{O}$ & 0.47 & Safranal \\
\hline 19.40 & 170 & $\mathrm{C}_{12} \mathrm{H}_{26}$ & 3.32 & n-Dodecane \\
\hline 19.48 & 156 & $\mathrm{C}_{10} \mathrm{H}_{20} \mathrm{O}$ & 0.87 & Decanal \\
\hline 19.82 & 184 & $\mathrm{C}_{13} \mathrm{H}_{28}$ & 0.38 & 4,8-Dimethylundecane \\
\hline 19.92 & 152 & $\mathrm{C}_{10} \mathrm{H}_{16} \mathrm{O}$ & 0.09 & Citral \\
\hline 20.04 & 184 & $\mathrm{C}_{13} \mathrm{H}_{28}$ & 0.09 & 4-Methyldodecane \\
\hline 20.16 & 139 & $\mathrm{C}_{7} \mathrm{H}_{9} \mathrm{NO}_{2}$ & 0.07 & 2-Ethyl-3-methyl-maleimide \\
\hline 20.32 & 374 & $\mathrm{C}_{21} \mathrm{H}_{42} \mathrm{O}_{3} \mathrm{~S}$ & 0.14 & Sulfurous acid, cyclohexylmethyl tetradecyl ester \\
\hline 20.46 & 198 & $\mathrm{C}_{14} \mathrm{H}_{30}$ & 0.60 & 4,6-Dimethyldodecane \\
\hline 20.70 & 198 & $\mathrm{C}_{14} \mathrm{H}_{30}$ & 1.31 & 2,6,10-Trimethyltridecane \\
\hline
\end{tabular}

Continued... 
Table 3: Cont'd.

\begin{tabular}{|c|c|c|c|c|}
\hline Retention Time (min) & Molecular Mass & Empirical Formula & Area\% & Putative Identification \\
\hline 20.94 & 190 & $\mathrm{C}_{14} \mathrm{H}_{22}$ & 10.71 & 1,3-bis(1,1-Dimethylethyl)-benzene \\
\hline 21.08 & 154 & $\mathrm{C}_{10} \mathrm{H}_{18} \mathrm{O}$ & 0.14 & 2-Decenal \\
\hline 21.54 & 184 & $\mathrm{C}_{13} \mathrm{H}_{28}$ & 0.26 & 11-Methyldodecane \\
\hline 21.61 & 168 & $\mathrm{C}_{12} \mathrm{H}_{24}$ & 0.03 & 7-Methyl-undecene \\
\hline 21.71 & 198 & $\mathrm{C}_{14} \mathrm{H}_{30}$ & 1.86 & 4,6-Dimethyldodecane \\
\hline 21.86 & 210 & $\mathrm{C}_{15} \mathrm{H}_{30}$ & 0.28 & 1-Pentadecene \\
\hline 21.94 & 114 & $\mathrm{C}_{8} \mathrm{H}_{18}$ & 0.45 & 3,3-Dimethylhexane \\
\hline 22.10 & 198 & $\mathrm{C}_{14} \mathrm{H}_{30}$ & 0.14 & 4,6-Dimethyl-docecane \\
\hline 22.31 & 212 & $\mathrm{C}_{15} \mathrm{H}_{32}$ & 0.34 & 2,6,11-Trimethyldodecane \\
\hline 22.42 & 200 & $\mathrm{C}_{13} \mathrm{H}_{28} \mathrm{O}$ & 1.25 & Isotridecanol \\
\hline 22.65 & 200 & $\mathrm{C}_{13} \mathrm{H}_{28} \mathrm{O}$ & 1.93 & n-Tridecan-1-ol \\
\hline 22.80 & 184 & $\mathrm{C}_{13} \mathrm{H}_{28}$ & 0.17 & 5-Methyl-5-propylnonane \\
\hline 22.88 & 168 & $\mathrm{C}_{12} \mathrm{H}_{24}$ & 1.32 & 7-Methyl-1-undecene \\
\hline 22.97 & 226 & $\mathrm{C}_{16} \mathrm{H}_{34}$ & 1.02 & Hexadecane \\
\hline 23.23 & 240 & $\mathrm{C}_{17} \mathrm{H}_{36}$ & 0.53 & Heptadecane \\
\hline 23.41 & 184 & $\mathrm{C}_{13} \mathrm{H}_{28}$ & 0.15 & 4-Methyldodecane \\
\hline 23.62 & 286 & $\mathrm{C}_{16} \mathrm{H}_{30} \mathrm{O}_{4}$ & 5.98 & 2,2,4-Trimethyl-1,3-pentanediol diisobutyrate \\
\hline 24.19 & 216 & $\mathrm{C}_{12} \mathrm{H}_{24} \mathrm{O}_{3}$ & 8.32 & Propanoic acid, 2-methyl-3-hydroxy-2,2,4-trimethypentyl ester \\
\hline 24.96 & 198 & $\mathrm{C}_{14} \mathrm{H}_{30}$ & 0.50 & Tetradecane \\
\hline 25.67 & 264 & $\mathrm{C}_{13} \mathrm{H}_{28} \mathrm{O}_{3} \mathrm{~S}$ & 0.04 & Sulfurous acid, decyl-2-propyl ester \\
\hline 27.83 & 193 & $\mathrm{C}_{13} \mathrm{H}_{20} \mathrm{O}$ & 0.06 & trans- $\beta$-Ionone \\
\hline 28.14 & 282 & $\mathrm{C}_{20} \mathrm{H}_{42}$ & 0.17 & n-Eicosane \\
\hline 28.37 & 296 & $\mathrm{C}_{21} \mathrm{H}_{44}$ & 0.73 & n-Heneicosane \\
\hline 28.86 & 206 & $\mathrm{C}_{14} \mathrm{H}_{22} \mathrm{O}$ & 0.19 & 2,4-Di-tert-butylphenol \\
\hline 29.50 & 180 & $\mathrm{C}_{11} \mathrm{H}_{16} \mathrm{O}_{2}$ & 0.87 & 5,6,7,7a-tetrahydro-4,4,7a-trimethyl-2 $(4 \mathrm{H})$-benzofuranone \\
\hline 29.81 & 184 & $\mathrm{C}_{13} \mathrm{H}_{28}$ & 0.04 & 5-Butylnonane \\
\hline 29.91 & 228 & $\mathrm{C}_{15} \mathrm{H}_{32} \mathrm{O}$ & 0.07 & 3,7,11-Trimethyl-1-dodecanol \\
\hline 30.00 & 352 & $\mathrm{C}_{16} \mathrm{H}_{33} \mathrm{I}$ & 0.05 & n-Hexadecyl iodide \\
\hline 30.42 & 210 & $\mathrm{C}_{15} \mathrm{H}_{30}$ & 0.04 & Nonylcyclohexane \\
\hline 30.51 & 338 & $\mathrm{C}_{24} \mathrm{H}_{50}$ & 0.12 & 11-Methyl-n-tricosane \\
\hline 30.68 & 256 & $\mathrm{C}_{16} \mathrm{H}_{32} \mathrm{O}_{2}$ & 0.04 & Palmitic acid \\
\hline 30.86 & 380 & $\mathrm{C}_{27} \mathrm{H}_{56}$ & 0.11 & 2-Methyl-hexacosane \\
\hline 31.08 & 296 & $\mathrm{C}_{21} \mathrm{H}_{44} \mathrm{O}$ & 0.10 & 8-Hexylpentadecane \\
\hline 31.67 & 368 & $\mathrm{C}_{24} \mathrm{H}_{48} \mathrm{O}_{2}$ & 0.10 & Ethyl docosanoate \\
\hline 31.78 & 286 & $\mathrm{C}_{16} \mathrm{H}_{30} \mathrm{O}_{4}$ & 0.80 & 1-Isobutyl-4-isopropyl-3-isopropyl-2,2-dimethylsuccinate \\
\hline 33.00 & 212 & $\mathrm{C}_{15} \mathrm{H}_{32} \mathrm{O}$ & 0.17 & Pentadecane \\
\hline 33.96 & 252 & $\mathrm{C}_{18} \mathrm{H}_{36}$ & 0.46 & n-Dodecyclohexane \\
\hline 33.43 & 356 & $\mathrm{C}_{22} \mathrm{H}_{44} \mathrm{O}_{3}$ & 0.04 & Carbonic acid, decyl undecyl ester \\
\hline 34.10 & 226 & $\mathrm{C}_{16} \mathrm{H}_{34}$ & 0.32 & 2,6,10-Trimethyltridecane \\
\hline 34.19 & 380 & $\mathrm{C}_{27} \mathrm{H}_{56} \mathrm{O}$ & 0.07 & 2-Methyl-n-hexacosane \\
\hline 34.96 & 208 & $\mathrm{C}_{15} \mathrm{H}_{28}$ & 0.06 & 1,3-Dicyclohexylpropane \\
\hline 35.03 & 254 & $\mathrm{C}_{18} \mathrm{H}_{38}$ & 0.02 & 2-Methyl-heptadecane \\
\hline 35.15 & 576 & $\mathrm{C}_{32} \mathrm{H}_{65} \mathrm{I}$ & 0.03 & 1-Iodo-dotriacontane \\
\hline
\end{tabular}

Continued... 
Table 3: Cont'd.

\begin{tabular}{ccccc}
\hline Retention Time $(\mathrm{min})$ & Molecular Mass & Empirical Formula & Area\% & Putative Identification \\
\hline 35.47 & 270 & $\mathrm{C}_{17} \mathrm{H}_{34} \mathrm{O}_{2}$ & 0.09 & Ethyl pentadecanoate \\
36.13 & 278 & $\mathrm{C}_{20} \mathrm{H}_{38}$ & 0.01 & Neophytadiene \\
36.19 & 268 & $\mathrm{C}_{18} \mathrm{H}_{36} \mathrm{O}$ & 0.50 & 6,10 , 14-Trimethyl-1-pentadecanone \\
36.48 & 278 & $\mathrm{C}_{16} \mathrm{H}_{22} \mathrm{O}_{4}$ & 0.76 & Diisobutyl phthalate \\
36.81 & 312 & $\mathrm{C}_{20} \mathrm{H}_{40} \mathrm{O}_{2}$ & 0.02 & Stearic acid, ethyl ester \\
37.20 & 256 & $\mathrm{C}_{16} \mathrm{H}_{32} \mathrm{O}_{2}$ & 0.43 & Methyl 12-methyltetradecanoate \\
37.57 & 652 & $\mathrm{C}_{38} \mathrm{H}_{68} \mathrm{O}_{8}$ & 0.02 & Ascorbic acid 2,6-dihexadecanoate \\
37.63 & 278 & $\mathrm{C}_{16} \mathrm{H}_{22} \mathrm{O}_{4}$ & 0.08 & Dibutyl phthalate \\
37.98 & 284 & $\mathrm{C}_{18} \mathrm{H}_{36} \mathrm{O}_{2}$ & 0.72 & Ethyl palmitate \\
38.06 & 184 & $\mathrm{C}_{13} \mathrm{H}_{28}$ & 0.02 & 5-Isobutylnonane \\
39.77 & 306 & $\mathrm{C}_{20} \mathrm{H}_{34} \mathrm{O}_{2}$ & 0.03 & Linolenic acid, ethyl ester \\
\hline
\end{tabular}

The $\%$ area is expressed as a $\%$ of the total area under all chromatographic peaks.

extracts against $\mathrm{CaCo} 2$ cells. $^{29}$ The phenolic acids and flavonoid components of the extracts may protect cells from oxidative stress by shielding lipids, proteins and DNA from oxidative damage, thereby blocking apoptosis.

GC-MS headspace analysis putatively identified a number of compounds that may contribute to the anti-proliferative activity of the C. maritima hexane extract. The presence of a several terpenoids was of particular interest. Indeed, the monoterpenoids 2-hydroxy-1,8-cineole (Figure 5a), limonene (Figure 5b) and citronellal (Figure 5c) were amongst the most abundant compounds identified in the extract. Additionally, the C. maritima hexane extract contained several other terpenoids in lower abundance. Safranal, cymene and citral were also detected in the C. maritima hexane extract, albeit in substantially lower relative abundance. Many monoterpenoids have anticancer properties and their antiproliferative properties have been extensively reported. Geraniol and iosgeraniol inhibit the proliferation of murine leukaemia, hepatoma and melanomas. ${ }^{30,31}$ Cineole, induces apoptosis in HCT116 and RKO human colon carcinoma cells by activating p38 and of caspase-3, as well as inactivating of Akt. ${ }^{32} \alpha$-Pinene treatment disrupts mitochondrial membrane potential in metastatic melanoma cells, increasing their production of ROS and thereby increasing caspase- 3 activity and DNA fragmentation, inducing apoptosis. ${ }^{33}$ Linalool and its derivatives have cytostatic and cytotoxic effects in leukaemia cell lines via activation of p53 and cyclin dependent kinase inhibitors. ${ }^{34}$ Of further note, linalool also reverses doxorubicin resistance in MCF7 AdrR multidrug resistant human breast adenocarcinoma cells and therefore potentiates the activity of doxorubicin. ${ }^{35}$ Furthermore, many plant extracts with anticancer activity have been reported to be abundant in monoterpenoids. ${ }^{17,36-38}$ It is therefore likely that the monoterpenoids detected in the C. maritima hexane extract may contribute to the anti-proliferative activity detected in our study. The sesquiterpenoid trans- $\beta$-ionone was also putatively identified in the C. maritima hexane extract, albeit in relatively low relative abundance. Multiple studies have also reported anticancer properties for sesquiterpenoids. Caryophyllene inhibits the cell cycle and induces apoptosis in human PC-3 prostate and MCF-7 breast cancer cell lines. ${ }^{39}$ Zingiberene supresses N2a-NB neuroblastoma cell proliferation via the induction of apoptosis. ${ }^{40}$ Similarly, phytol induces cellular apoptosis and inhibits proliferation in Molt $4 \mathrm{~B}$ human leukaemia cells. ${ }^{41}$ It is therefore possible that trans- $\beta$-ionone may have similar properties and may contribute to the anticancer properties of the $C$. maritima hexane extract.

The findings reported here also demonstrate that all C. maritima extracts were nontoxic towards Artemia franciscana nauplii. Extracts with $\mathrm{LC}_{50}$ values $>1000 \mu \mathrm{g} / \mathrm{mL}$ towards Artemia nauplii have been defined as being nontoxic. ${ }^{25}$ However, further studies using human cell lines are required to verify the safety of these extracts for therapeutic use. Furthermore, bioactivity driven separation studies are required to isolate the active components and determine their mechanism of action.

\section{CONCLUSION}

The results of this study demonstrate the potential of C. maritima extracts to block the growth of HeLa and $\mathrm{CaCO} 2$ cell lines. In particular, the hexane and ethyl acetate extracts were identified as particularly potent inhibitors of $\mathrm{CaCO} 2$ and HeLa cell proliferation. Furthermore, all extracts were nontoxic in the Artemia nauplii bioassay, indicating their therapeutic potential. A number of interesting compounds that may contribute to the extracts anticancer activity were identified by GC-MS. However, the anti-proliferative mechanisms of the extracts were not examined in this study. Further studies aimed at identifying the anti-proliferative mechanisms of these extracts are needed.

\section{ACKNOWLEDGEMENT}

Financial support for this work was provided by the Environmental Futures Research Institute, Griffith University and the Pharmaceutical and Drug Division, National Research Centre, Giza, Egypt.

\section{CONFLICT OF INTEREST}

The authors declare no conflict of interest.

\section{ABBREVIATIONS}

CACO2: A human colorectal cancer cell line; DMSO: Dimethyl sulfoxide; DPPH: 2,2-diphenyl-1-picrylhydrazy; GC-MS: Gas chromatography-mass spectrometry; HeLa: A human cervical cancer cell line; $\mathrm{IC}_{50}$ : The concentration required to achieve $50 \%$ effect; $\mathbf{L C}_{50}$ : The concentration required to achieve $50 \%$ mortality; MTS: 3-(4,5-dimethylthiazol2-yl)-5-(3-carboxymethyoxyphenyl)-2-(4-sulfophenyl)-2H-tetrazolium; RPMI: Roswell Park Memorial Institute; ZOI: Zone of inhibition.

\section{REFERENCES}

1. Halliwell B, Gutteridge MCJ. Free radicals in biology and medicine. $3^{\text {rd }}$ ed, Oxford University Press, Oxford. 1999.

2. Hertog MG, Bueno MHB, Fehily AM, Sweetnam PM, Elwood PC, Kromhout D. Fruit and vegetable consumption and cancer mortality in the caerphilly study. Cancer Epidemiology. Biomarkers and Prevention. 1996;5(9):673-7.

3. Shalom J, Cock IE. Terminalia ferdinandiana Exell. fruit and leaf extracts inhibit proliferation and induce apoptosis in selected human cancer cell lines. Nutrition and Cancer. 2018;70(4):579-93. DOI: 10.1080/01635581.2018.1460680 
4. Brown NS, Bicknell R. Hypoxia and oxidative stress in breast cancer. Oxidative stress: its effects on the growth, metastatic potential and response to therapy of breast cancer. Breast Cancer Research. 2001;3(5):323-7.

5. Tome ME, Baker AF, Powis G, Payne CM, Briehl MM. Catalase-overexpressing thymocytes are resistant to glucocorticoid-induced apoptosis and exhibit increased net tumor growth. Cancer Research. 2001;61(6):2766-73.

6. Holmgren A. Antioxidant function of thioredoxin and glutaredoxin systems. Antioxidants and Redox Signaling. 2000;2(4):811-20.

7. Gey KF. Cardiovascular disease and vitamins: concurrent correction of 'suboptimal' plasma antioxidant levels may, as an important part of 'optimal' nutrition, help to prevent early stages of cardiovascular disease and cancer, respectively. Bibliotheca Nutritioet Dieta. 1995;52:75-91.

8. Rice-Evans C, Miller N, Paganga G. Antioxidant properties of phenolic compounds. Trends in Plant Science. 1997;2(4):152-9.

9. Meot-Duros L, Le Floch G, Magné C. Radical scavenging, antioxidant and antimicrobial activities of halophytic species. Journal of Ethnopharmacology. 2008; 116(2):258-62

10. Guil-Guerrero JL, Giménez-Martinez JJ, Torija-Isasa ME. Nutritional composition of wild edible crucifer species. Journal of Food Biochemistry. 1999;23(3):283-94.

11. Cock IE. The phytochemistry and chemotherapeutic potential of Tasmannia lanceolata (Tasmanian pepper): A review. Pharmacognosy Communications. 2013;3(4):13-25. DOI: 10.5530/pc.2013.4.3

12. Courtney R, Sirdaarta J, Matthews B, Cock IE. Tannin components and inhibitory activity of Kakadu plum leaf extracts against microbialtriggers of autoimmune inflammatory diseases. Pharmacognosy Journal. 2015;7(1):18-31. DOI: 10.5530/ pj.2015.7.2

13. Sirdaarta J, Matthews B, White A, Cock IE. GC-MS and LC-MS analysis of Kakadu plum fruit extracts displaying inhibitory activity against microbialtriggers of multiple sclerosis. Pharmacognosy Communications. 2015;5(2):100-15. DOI: 10.5530/pc. 2015.2 .2

14. Sirdaarta, J, Matthews B, Cock IE. Kakadu plum fruit extracts inhibit growth of the bacterial triggers of rheumatoid arthritis: Identification of stilbene and tannin components. Journal of Functional Foods. 2015;17:610-20. DOI: 10.1016/j. jff.2015.06.019

15. Sautron C, Cock IE. Antimicrobial activity and toxicity of Syzygium australe and Syzygium leuhmannii fruit extracts. Pharmacognosy Communications. 2014;4(1):53-60. DOI: 10.5530/pc.2014.1.8

16. Winnett $\mathrm{V}$, Boyer $\mathrm{H}$, Sirdaarta J, Cock IE. The potential of Tasmannia lanceolata as a natural preservative and medicinal agent: Antimicrobial activity and toxicity. Pharmacognosy Communications. 2014;4(1):42-52. DOI: 10.5530/pc.2014.1.7

17. Omer E, Elshamy A, EI Gendy AN, Cai X, Sirdaarta J, White A, Cock IE. Cakile maritima Scop. Extracts inhibit the growth of some bacterial triggers of autoimmune diseases: GC-MS analysis of an inhibitory extract. Pharmacognosy Journal. 2016;8(4):361-74. DOI: 10.5530/pj.2016.4.9

18. McManus K, Wood A, Wright MH, Matthews B, Greene AC, Cock IE. Terminalia ferdinandiana Exell. extracts inhibit the growth of body odour-forming bacteria. International Journal of Cosmetic Science. 2017;39(5):500-10.

19. Winnett V, Sirdaarta J, White A, Clarke FM, Cock IE. Inhibition of Klebsiella pneumonia growth by selected Australian plants: natural approaches to the prevention and management of ankylosing spondylitis. Inflammopharmacology. 2017;25(2):223-35

20. Wright MH, Arnold MSJ, Aldosary H, Sirdaarta J, Geene AC, Cock IE. Bioactive constituents of Terminalia ferdinandiana Exell: A pharmacognostic approach towards the prevention and treatment of yersiniosis. Pharmacognosy Communications 2016;6(3):152-63. DOI: 10.5530/pc.2016.3.5

21. Arkhipov A, Sirdaarta J, Rayan P, McDonnell PA, Cock IE. An examination of the antibacterial, antifungal, anti-Giardial and anticancer properties of Kigelia africana fruit extracts. Pharmacognosy Communications. 2014;4(3):62-76.

22. Lee CJ, Wright MH, Arnold MSJ, Greene AC, Cock IE. Inhibition of Streptococcus pyogenes growth by native Australian plants: New approaches towards the management of impetigo, pharyngitis and rheumatic heart disease. Pharma-

\section{GRAPHICAL ABSTRACT}

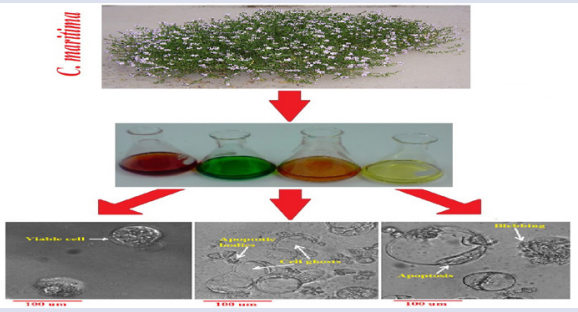

cognosy Communications. 2016;6(3):164-73. DOI: 10.5530/pc.2016.3.6

23. Hart C, Ilanko P, Sirdaarta J, Rayan P, McDonnell PA, Cock IE. Tasmannia stipitata as a fdunctional food/natural preservative: Antimicrobial activity and toxicity. Pharmacognosy Communications. 2014;4(4):33-47. DOI: 10.5530/pc.2014.4.4

24. Biggs I, Sirdaarta J, White A, Cock IE. GC-MS analysis of frankincense extracts which inhibit the growth of bacterial triggers of selected autoimmune diseases. Pharmacognosy Communications. 2016;6(1):10-22. DOI: 10.5530/pc.2016.1.3

25. Cock IE, Ruebhart DR. Comparison of the brine shrimp nauplii bioassay and the ToxScreen-II test for the detection of toxicity associated with Aloe vera (Aloe barbadensis Miller) leaf extract. Pharmacognosy Research. 2009;1(2):102-8.

26. Cock IE. Problems of reproducibility and efficacy of bioassays using crude extracts, with reference to Aloe vera. Pharmacognosy Communications. 2011;1(1):52-62

27. Rahman A, Hadi SM, Parish JH. Complexes involving quercetin, DNA and Cu(II). Carcinogenesis. 1990;11(11):2001-3.

28. Singh S, Farhan AS, Ahmad A, Khan NU, Hadi SM. Oxidative DNA damage by capsaicin and dihydrocapsaicin in the presence of $\mathrm{Cu}$ (II). Cancer Letters. 2001;169(12):139-46.

29. Eberhardt MV, Lee CY, Liu RH. Nutrition: Antioxidant activity of fresh apples. Nature. 2000;405(6789):903-4.

30. Yu SG, Hildebrandt LA, Elson CE. Geraniol, an inhibitor of mevalonate biosynthesis, suppresses the growth of hepatomas and melanomas transplanted to rats and mice. Journal of Nutrition. 1995;125(11):2763-7.

31. Shoff SM, Grummer M, Yatvin MB, Elson CE. Concentration dependent increase of murine P388 and B16 population doubling time by the acyclic monoterpene geraniol. Cancer Research. 1991;51(1):37-42.

32. Murata S, Shiragami R, Kosugi C, Tezuka T, Yamazaki M, Hirano A, et al. Antitumor effect of 1, 8-cineole against colon cancer. Oncology Reports. 2013;30(6):2647-52 DOI:10.3892/or.2013.2763.

33. Matsuo AL, Figueiredo CR, Arruda DC, Pereira FV, Scutti JAB, Massaoka MH, et al. $\alpha$-Pinene isolated from Schinusterebinthifolius Raddi (Anacardiaceae) in duces apoptosis and confers antimetastatic protection in a melanoma model. Biochemical and Biophysical Research Communications. 2011;411(2):449-54.

34. GuY, Ting Z, Qiu X, Zhang X, Gan X, Fang Y, et al. Linalool preferentially induces robust apoptosis of a variety of leukemia cells via upregulating p53 and cyclindependent kinase inhibitors. Toxicology. 2010;268(1):19-24

35. Ravizza R, Gariboldi MB, Molteni R, Monti E. Linalool, a plant-derived monoterpene alcohol, reverses doxorubicin resistance in human breast adenocarcinoma cells. Oncology Reports. 2008;20(30):625-30.

36. da Silva CE, Minguzzi S, da Silva RC, Matos MF, Tofoli D, Carvalho JED, et al Chemical composition and cytotoxic activity of the root essential oil from Jatropha ribifolia (Pohl) Baill (Euphorbiaceae). Journal of the Brazilian Chemical Society. 2015;26(2):233-8.

37. Taherkhani M, Rustaiyan A, Taherkhani T. Composition of the leaf essential oils of Artemisia ciniformis Krasch. et M. Pop. exPoljak, Artemisia oliveriana J. Gay ex Bess. in DC. And Artemisia turanica Krasch, three Asteraceae herbs growing wild in Iran. Journal of Essential Oil Bearing Plants. 2012;15(6):1006-12.

38. Tundis R, Loizzo MR, Menichini F, Bonesi M, Colica C, Menichini F. In vitro cytotoxic activity of extracts and isolated constituents of Salvia leriifolia Benth. against a panel of human cancer cell lines. Chemistry and Biodiversity. 2011;8(6):1152-62

39. Park KR, Nam D, Yun HM, Lee SG, Jang HJ, Sethi G, et al. $\beta$-Caryophyllene oxide inhibits growth and induces apoptosis through the suppression of PI3K/ AKT/mTOR/S6K1 pathways and ROS-mediated MAPKs activation. Cancer Letters. 2011;312(2):178-88.

40. Togar B, Turkez H, Tatar A, et al. Cytotoxicity and genotoxicity of zingiberene on different neuron cell lines in vitro. Cytotechnology. 2015;67(6):1-8.

41. KomiyaT, Kyohkon M, Ohwaki S, Eto J, Katsuzaki H, Imai K, et al. Phytol induces programmed cell death in human lymphoid leukemia Molt 4B cells. International Journal of Molecular Medicine. 1999;4(4):377-457.

\section{SUMMARY}

- All C. maritima solvent extracts had strong DPPH radical scavenging activity (IC $\mathrm{C}_{50}$ 3.4-13.6 $\mathrm{\mu g} / \mathrm{mL}$ respectively)

- All extracts inhibited $\mathrm{Caco} 2$ and HeLa proliferation and this activity did not cor respond with antioxidant activity.

- The hexane extract had the most potent anti-proliferative activity $\left(I C_{50}\right.$ 's of 12 and $126 \mu \mathrm{g} / \mathrm{mL}$ respectively against Caco2 and HeLa respectively).

- All C. maritima extracts were non-toxic in the the A. franciscana bioassay

- GC-MS profiling highlighted several compounds that may contribute to the anti-proliferative activity of the hexane extract.

Cite this article: Omer E, Elshamy Al, Taher RF, El-Kashak WA, Shalom J, White AA, Cock I. Cakile maritima Scop. Extracts Inhibit Caco2 and HeLa Human Carcinoma Cell Growth: GC-MS Analysis of an Anti-Proliferative Extract. Pharmacog J. 2019;11(2):258-66. 